\title{
The Interactivity of ICT in Language Teaching in the Context of Ukraine University Education
}

\author{
Nataliya M. Savchuk ${ }^{1}$, Svitlana A. Sichkar ${ }^{1}$, Iryna V. Khlystun ${ }^{1}$, Svitlana A. Shuliak ${ }^{1} \&$ Valentina I. Avramenko $^{1}$ \\ ${ }^{1}$ Practical Linguistics Department, Pavlo Tychyna Uman State Pedagogical University, Uman, Ukraine \\ Correspondence: Nataliya M. Savchuk, Practical Linguistics Department, Pavlo Tychyna Uman State Pedagogical \\ University, 28 Sadova str., Uman, 20300, Ukraine. E-mail: 1981phd@gmail.com
}

Received: July 30, 2019

doi:10.5430/ijhe.v8n5p84
Accepted: August 14, 2019

Online Published: August 19, 2019

\begin{abstract}
The purpose of the study is to examine and evaluate the impact the the multimedia textbook-based interactive, based on ICT model learning environment provides for the learning styles of the university students majoring in Philology. The study sought to identify tangible (seemingly measurable) and intangible (difficult to measure) gains this learning model brought to both students and instructors. A multimedia textbook to deliver the course in Urkainian Languge was developed for the study. A multi method approach was used to gather feedback and quantitative methods were used to analyze the data. Specifically, Covariance-based Structural Equation Modeling (SEM) software as SPSS AMOS and Textalyzer were used to process the students' responses to survey questions. The results reported a shift in student preferences in learning, including a greater desire to engage independently with computer-assisted work, quicker problem solving, increased motivation to study, and improved time management and lifelong learning skills. Additionally, there was a shift in teaching approaches of the instructors, namely from a teacher-centered to a student-centered approach. The study may better inform building the learning process for the students with limited learning opportunities or studying the distance learning model. Despite the experimental group involving only the students majoring in Philology, this methodology could be applicable to teaching Ukraninan for Specific Purposes to other majors, such as: Psychology, Law, Cultorology. The research is advancing the knowledge of integration ICT (multimedia) tools into teaching, and specifically the use of multimedia textbooks to deliver Ukrainian English course to the students majoring in Philology.
\end{abstract}

Keywords: interactive education, ICT, interactive means, interactive model of teaching, higher educational establishment

\section{Introduction}

Modern global changes in the world and in Ukraine (economic, political, social, etc.) put forward new requirements for the personal qualities and professional competences of students of philological faculties graduating from the higher educational establishments, who should correspond to the present labor market. Accordingly, the development of competence, activity, practice and personality-oriented approaches, the study of the interactive approach in higher education in general and in the teaching of the native (Ukrainian) language of students of philological faculties in particular are a matter of particular interest. In the most general form, under interactive learning, we understand the interaction of all participants in the educational process among themselves and the learning environment in which the teacher creates conditions for activating of the educational activity of students and acts as its organizer (Gradov, 2010).

The purpose of the paper is to highlight interactive means as key elements of information and communication technologies in teaching the Ukrainian language at higher educational establishments. The realization of this purpose involves solving the corresponding objectives: to clarify the essence of the concepts of "information and communication technologies", "interactive model of teaching", "interactive teaching methods"; to name the key interactive tools used in teaching the Ukrainian language at the higher educational establishments. In the conducted research, the following methodological algorithm was used: on the one hand, traditional methods: theoretical (analysis of philosophical, social, psychological and pedagogical literature, dissertations / theses, scientific materials and publications, their systematization, classification, comparative analysis, modeling, etc); empirical (methodological observation), and, on the other hand, modern approaches, including diagnostic (determinant), research and experimental (basic) and analytical stages. 


\subsection{Interactivity of ICT in Language Teaching}

Specialists studied aspects of interactive learning such as "speech interaction, psychology of teachers and students' interactions, dialogue communication, the process of common knowledge through means of dialogue (polylogue), involvement of students in educational activity and its reflection" (Korotaeva, 2003). In addition, the emphasis of the research was focused on the study of the probability of a combination of "interactive methods with traditional" (Almazova, 2003), as well as on the study of the impact of "interactive learning on the development of creative abilities of students" (Kolesnikova \& Dolgina, 2008).

In the works of foreign scholars, "the problem of interactive learning within language acts" (Bloom, 1976) was outlined; "the role of the teacher in the organization of interactive learning" (Fleming \& Baume, 2006) was analyzed, and some experts were concerned "with interactive learning in terms of motivation of students for common cognitive activity" and paid attention to mastering of "competencies" (Burns \& Myhill, 2004); considered interactive learning as a two-way process in which the teacher stimulates students to show greater activity (Hall \& Verplaetse, 2000); as well as focused on the technology of interactive learning of foreign languages (Brown \& Campione, 1994). However, despite a number of works devoted to various aspects of interactive learning, as a rule, in psychological and methodological aspects, in the modern methodology questions related to the positions of participants in the educational process remain open, particularly in the content of the "The Ukrainian Language" discipline concerning interactivity.

\subsection{The Use of Multimedia Tools}

The use of multimedia tools in teaching has proven to enhance teaching effects (Almarabeh et al., 2015; Gunawardhana \& Palaniappan, 2016b). It has changed the ways instructors and researchers explore educational concepts as it provides convenience, drastically changes the learning experience of students, and it increases student involvement in the learning process. Multimedia tools support the teacher by supplying additional educational elements to students' cognitive process (Gunawardhana \& Palaniappan, 2016a), therefore, using a multimedia textbook as a tool to teach Ukrainian Language to future Philolgists is worthy of discussion.

This research was inspired by the easy-to-adjust nature of the multimedia textbook-based interactive, based on ICT model as it is related to the concept of creating a hybrid, or blended learning and problem-based learning environment to engage students in active learning through the use of new technologies (Arnold-Garza, 2014). The latter moves the lecture outside of class and enables using class time more efficienly dedicating it to the practical application assignments (Educause, 2012). Therefore, the above learning mode is viewed as a pedagogical approach based on reversing the roles of individual and group space resulting the latter is transformed into a dynamic, interactive learning environment guided by the educator and in which students are supported by peers as apply concepts and participate creatively in the subject matter (Giannakos et al., 2018).

In view of the above, the the multimedia textbook-based interactive based on ICT model is likely to best suit the state policy in Language teaching in Ukraine (Bolitho \& West, 2017) due to a number of its advantages (Arnold-Garza, 2014), such as: the efficient use of time during the class, provision the students with a more interactive learning environment, provision of increased student and teacher personal collaboration and interaction, shifting responsibility for learning from a teacher to a student, and consideration of students' learning styles.

Integrating ICT tools into teaching is being widely discussed by scholars (Babiker, 2015; Udim \& Etim, 2016; Norlis et al., 2018), but this discussion is still rather theoretical. For this reason, many aspects of the use of interactive multimedia tools used for teaching purposes are open to discussion (Thamarana, 2016).

Therefore, to identify the effects of the interactive learning model supported by ICT on the students' educational activity and academic achievement at tertiary schools in Ukraine, this study aims to answer the following research questions:

1. To what extent does the interactive learning model supported by ICT stimulate students' learning activity and improves their academic performances?

2. What are the opinions of students about the model?

\section{Methodological Framework}

This research relies on empirical and statistical methods used for conducting an experimental study of teaching the Ukrainian Language course to the students majoring in Philology using the interactive learning model supported by ICT. The latter was based on the use of a multimedia textbook delivered through interactive equipment like interactive whiteboard, tablet, plasma display, mobile devices, projectors, testing systems, small IT tools. To meet the 
research objective, this study used a mixed-methods approach based on collection quantitative data to obtain the overall picture of a problem and qualitative data to reveal explanatory details. The flipped classroom and traditional teaching use resulted data were considered independent variables of the research while students' academic achievements were the dependent variable.

The study was a continuous flow of three stages: (1) empirical - to study the current state of teaching Ukrainian Language at tertiary schools using using the interactive learning model supported by ICT, developing and piloting a content of a multimedia textbook; (2) experimental - to do placement tests, needs analysis questionnaires, face-to-face sessions, tutorials, project-based learning conducted both traditionally (offline), and with the multimedia book to have been integrated into the course; (3) analytic - to process the experimental data collected.

\subsection{Data Collection Tools}

Multiple data collection tools were used in this study. An achievement test was used to respond the first research question. Focus group surveys, on the other hand, were used to answer the second research question.

\subsection{Achievement Test}

Given the time allocated to each topic, the 23 multiple-choice-item-test was designed and then evaluated by three knowledge field experts and the expert in the field of measurement and evaluation. The test items were aimed to distinguished between students who are masters and non-masters. To validate the test internal reliability, it was run the Kuder-Richardson Formula 20, resulted in a reliability coefficient, which was 0.74 and indicates internal reliability.

\subsection{Focus-Group Survey}

To increase the validity of the results, a detailed literature review in the relevant field was performed before the survey questions were developed. Textalyser was used in the analysis procedure. A total of 14 students ( 7 male and 7 female students) were involved in the focus group surveys including. The questionnaire consisted of 5 below questions:

1) How much study time per week did you dedicate to doing the activities from the multimedia textbook?

2) What kind of activities did you specifically do?

3) What are the benefits of using a textbook of this kind for you?

4) What are the problems you faced when using this multimedia textbook?

5) What do you suggest doing to solve the problems you experienced?

\subsection{Data Analysis}

In order to analyze the quantitative data, a $2 \mathrm{X} 2$ split-plot design was used. There was used two-way ANOVA for Mixed Measures to designate the main effects for column and row factors and their interaction effect related to the efficacy of the experiment (Büyüköztürk, 2016). The data obtained through the survey were organized according to the themes and were analyzed though descriptive analysis. When analyzing, to ensure validity, a coding list was formed, and these codings were peer reviewed. Upon finishing analyses, another expert coded and interpreted some parts of the interview data by means the same coding list. The results of the two analyses were compared, and the differences were discussed and negotiated.

\subsection{Study Group}

At the empirical stage, surveys were conducted among 544 teachers/lecturers and undergraduates for Uman State Pedagogical University named after Pavlo Tychyna, Cherkasy National University named after Bohdan Khmelnytsky and National Pedagogical University named after Mikhailo Drahomanov majoring in Philology to investigate the state of teaching Ukrainian Language. Due to application of exclusion criteria list such as: student age, major, teacher/lecture willingness to implement the interactive learning model supported by ICT in their work, location of the institution, the population was reduced by 436 people and it was obtained the population size of 108 people. In order to determine the sample size to ensure the quality and reliability representativeness, the Sample Size Calculator (Google Apps) was used. It was established that $\mathrm{N}$ (population size) $=108$, confidence interval $=8.96$, and $\mathrm{e}=.05$ at $95 \%$ confidence level. Therefore, the required sample size obtained was 57 people and this number was used to form the experimental and control groups for this study. Both groups were formed from the students of Uman State Pedagogical University named after Pavlo Tychyna.

The control and experimental groups of students were mostly homogeneous in terms of demographic and performance indicators, namely the control group numbered 27 people, of which 18 were young women aged 20-21 
and 9 young men aged 20-22. Of 29 individuals in the experimental group, 14 were young women aged 20-21 and 15 were young men aged 20-22. All participants of the study were students of the $3^{\text {rd }}$ year full-time, 014 Secondary Education (Ukrainian Language and Literature) Field of Knowledge ref. 03-Humanities (Philology).

The $t$-test was administered to identify whether there were any statistically significant differences between the pre-test scores of the two groups (see Table 1).

Table 1. The Results of the T-test According to the Pre-test Scores of the Groups

\begin{tabular}{ccccccc}
\hline Group & $n$ & \multicolumn{5}{c}{ Measurement } \\
\cline { 3 - 7 } & & $M$ & $S D$ & $S E$ & t-test & $p$ \\
\hline Experimental group & 29 & 3,5010 & 1,13845 & 56 & 0.71 & 0.477 \\
Control group & 27 & 3,2902 & 1,11395 & & & \\
\hline
\end{tabular}

Note. $\mathrm{P}<.05 ; \mathrm{n}$, the number of students; $\mathrm{M}$, arithmetic average; SD, standard deviations; SE, standard error.

Table 1 shows that both groups can participate in the experimental process as there were no statistically significant inconsistences between the mean scores of the students $(\mathrm{t}(56)=0.71, \mathrm{p}>0.05)$.

\subsection{Results}

The experiment was carried out in the natural conditions of the educational process, optionally. And the suggested model contributed to the student's academic achievements. The below table (see Table 2) illustrates the standard deviation values and the means of the pre-and post-test scores of the students in the experimental and control groups.

Table 2. Achievement Test Scores of the Experimental and Control Groups

\begin{tabular}{ccccc}
\hline Group & \multicolumn{2}{c}{ Pre-test } & \multicolumn{2}{c}{ Post-Test } \\
\cline { 2 - 5 } & $M$ & $S D$ & $M$ & $S D$ \\
\hline Experimental & 59.31 & 18.876 & 54.22 & 16.14 \\
Control & 55.48 & 18.46 & 57.62 & 12.97 \\
\hline
\end{tabular}

Note. SD - standard deviations; $\mathrm{M}$ - arithmetic average.

It is noteworthy that while the figures (mean scores) for pre- and post-test for the experimental group decreased (from 59.31 to 54.22), the figures (mean scores) for the control group increased (from 55.48 to 57.62).

Table 3 shows whether the changes in the students' scores show statistically significant differences and depend on the model used to teach them: the interactive learning model supported by ICT or traditional (paper course-book-based).

Table 3. The Results of ANOVA for Mixed Measures on the Students' Pre- and Post-test Scores depending on the use of either an interactive learning model supported by ICT or traditional (paper course-book-based) models

\begin{tabular}{cccccccc}
\hline Variance Source & $\boldsymbol{S S}$ & $\boldsymbol{d} \boldsymbol{f}$ & $\boldsymbol{M S}$ & $\boldsymbol{F}$-value & $\boldsymbol{P}$ & $\boldsymbol{\eta}^{2}$ & $\boldsymbol{n}$ \\
\hline Between-Groups & 23001.27 & 57 & & & & & \\
Group(Experimental/Control) & 32.44 & 1 & 33.34 & .082 & .773 & 0.001 & 57 \\
Error & 22959.48 & 56 & 412.49 & & & & \\
Within-Groups & 10841.72 & 58 & & & & & \\
Measurement/Pre-test/Post-test) & 11.24 & 1 & 11.24 & .059 & .798 & 0.001 & 57 \\
Group*Measurement & 168.31 & 1 & 168.31 & .899 & .344 & 0.016 & \\
Error & 10579.03 & 57 & 186.165 & & & & \\
Total & 20683.07 & 117 & & & & &
\end{tabular}

Note. $p>.05$; ANOVA, analysis of variance; $S S$ - sum of squares; $d f$ - degrees of freedom; $M S$ - mean square; $\eta^{2}$ measure of strength of relationship (eta squared); $n$ - the number of students.

It cannot be observed statistically substantial difference between the mean scores of the students learning through the interactive learning model supported by ICT and traditional mode. There was even a small decrease observed in the mean scores of the students taught through the interactive learning model supported by ICT as seen in Table 2 .

To address the relationship between the interactive learning model supported by ICT and improvement of students' learning activity, the descriptive statistics related to the variables of the research (learning readiness, academic motivation, and perceived learning) and the correlations between them were examined (see the results in Table 4). 
Table 4. Descriptive Statistics and Correlations Between Variables

\begin{tabular}{cccc}
\hline Variables & 1 & 2 & 3 \\
\hline $\begin{array}{c}\text { 1. Learning Readiness } \\
\text { (LR) }\end{array}$ & 1.00 & & \\
$\begin{array}{c}\text { 2. Academic Motivation } \\
(\text { AM) }\end{array}$ & $.41^{* *}$ & 1.00 & 1.00 \\
$\begin{array}{c}\text { 3. Perceived Learning } \\
\text { (PL) }\end{array}$ & $.69^{* *}$ & $.43^{* *}$ & $17.37(3.47)$ \\
$\begin{array}{c}\text { Mean (Likert type mean } \\
\text { score) }\end{array}$ & $74.13(4.11)$ & $140.03(5.00)$ & 3.97 \\
Standard Dev. & 11.70 & 24.29 & \\
\hline
\end{tabular}

$* p>.05 . * * p<.01$.

As it is seen in the Table 4, there are positive and significant correlations between LR, AM and PL figures. It was found that there is a positive noteworthy relationship between LR and AM $(r=.41, p>.05)$; a positive substantial relationship between LR and PL is also observed $(r=.69, p>.05)$; and there is a positive noteworthy relationship between AM and PL $(r=.43, p>.05)$. All correlation values are positive which means that the interactive learning model supported by ICT stimulates students' learning activity.

\subsection{Results of Processing Student Opinions Obtained Through a Focus Group Survey}

1) How much study time per week did you dedicate to doing the activities from the multimedia textbook? The participants were asked how much time they spent on performing the activities from the multimedia textbook a week. 2 out of 12 stated they dedicated-two hours to do the above, 2 students reported spending three-four hours, while the other students spent four-five hours.

2) What kind of activities did you specifically do? When asked what the students specifically did, they primarily mentioned doing web-research to perform project work (4 out of 12 people), collect information for presentations ( 9 out of 12 respondents), reviewing and drafting documents (7 students), watching instructional video (11 students).

3) What are the benefits of using a textbook of this kind for you? To respond this question the students stated that they were able to apply professionalism-related knowledge into practice (11 students), to increase their academic performance ( 7 students), to experience the settings and specifics of their job ( 9 students), to raise their confidence and motivation (10 students).

4) What are the problems you faced when using this multimedia textbook? When asked what problems the students encountered while learning through participating in this experimental mode, 2 out of 12 stated they sometimes experienced motivation problems, 9 students said they were challenged with the content, 2 students faced problems related to learning mode and 1 - procrastinated all the time.

5) What do you suggest doing to solve the problems you experienced? As for the students' suggestions to resolve the problems, 2 out 12 students responded they would give preference to course-book-based learning to deter deal with the content, 5 suggested increasing the amount of face-to-face portion of instruction.

Below, we graphically present (see Figures 1 and 2 below) the dynamics of the interactive learning model supported by ICT (multimedia textbook) influence on the development of value-motivational, cognitive and activity-reflexive components of the educational activity of students of control and experimental groups using a 5-point scale.

Comparing the visualized indicators of the degree development of value-motivational, cognitive and activity-reflexive components of the educational activity of the students of control and experimental groups before and after the experimental stages, we note the positive dynamics of the influence of gamification on the development of the above-mentioned components of educational activity in the process of studying professional-oriented courses in higher education institutions. In contrast to the control group, where the growth of the indicators was relatively smooth and insignificant, in the experimental group the largest changes occurred in the activity-reflexive component and amounted to 1.2 points of growth, while the same increase occurred in the other two components with a difference of 0.7 in the cognitive component and 0.6 in value-motivational one. 


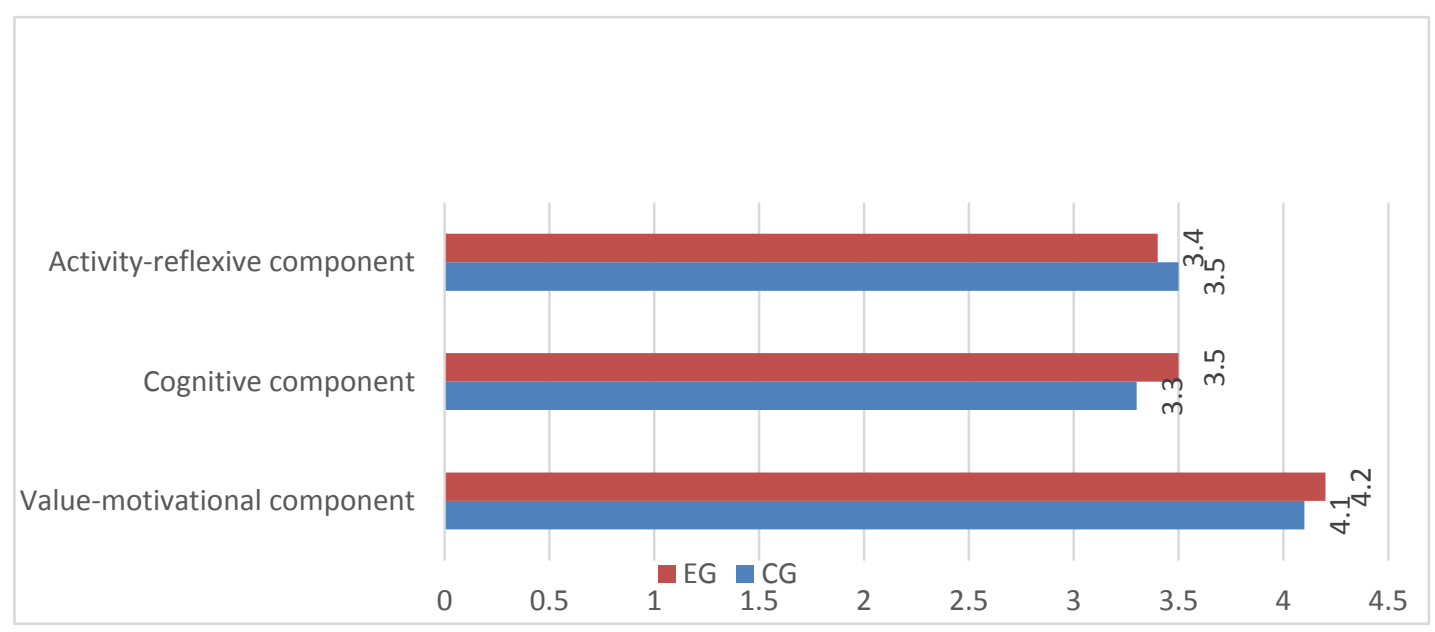

Figure 1. Progression of development of value-motivational, cognitive and activity-reflexive components of educational activity of students of control and experimental groups at the beginning of the experiment

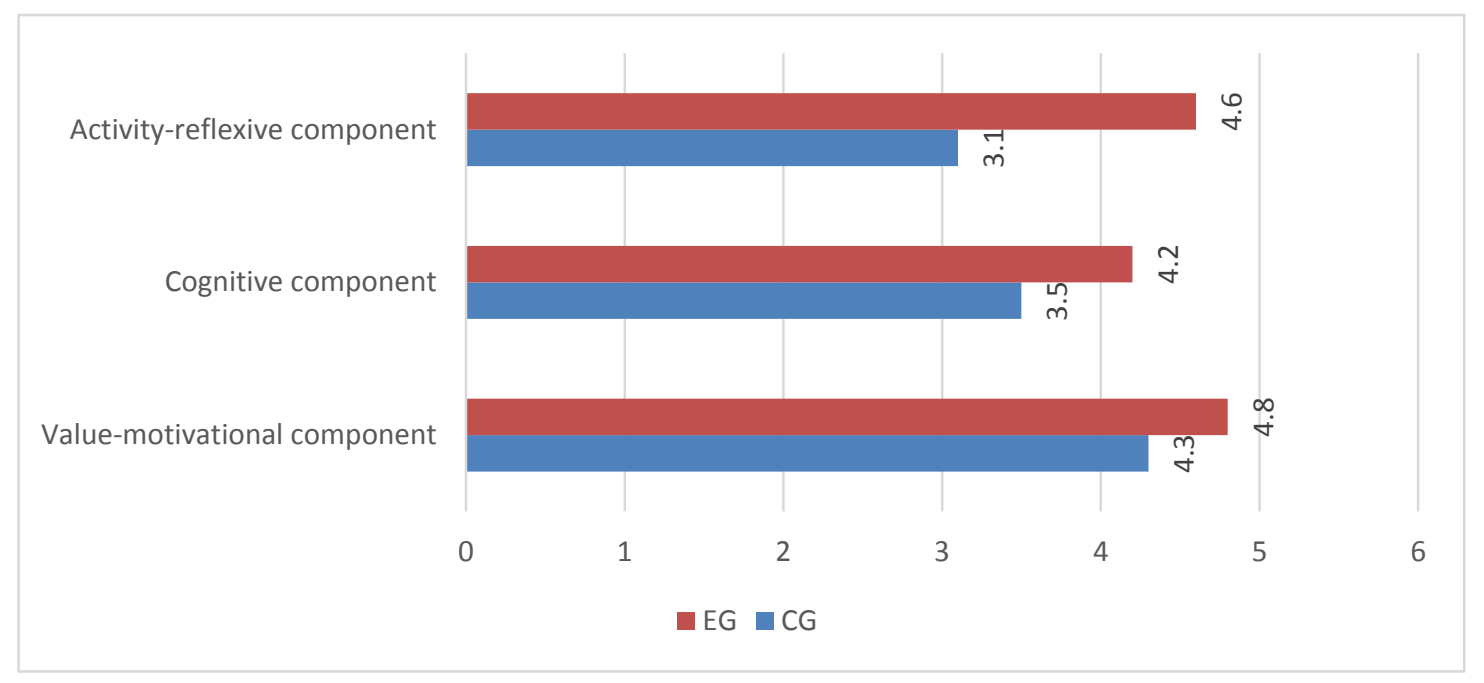

Figure 2. Progression of development of value-motivational, cognitive and activity-reflexive components of educational activity of students of control and experimental groups after the treatment

Moreover, $84 \%$ focus group students surveyed after the treatment reported improvement of their academic achievements in those professionalism-related courses where internet research is required and Achievement Post-Test Scores showed a positive change of approximately $11 \%$.

\subsection{Restrictions of the Study}

The main restriction of this study is the participation of only one higher educational institution in it. One more restriction can be considered the age category of students of control and experimental groups, because only bachelor qualification level students of the $3 \mathrm{r}^{\mathrm{d}}$ year were involved in the experiment. Prejudice of the members of the research group can also be considered a restriction, as some of them were involved in the development of the learning/teaching model, content of the multimedia coursebook, the methodology of the organization and carrying out the experiment. Additional research with different participants (students or university lecturers) could fruitful the data. A more extended quantitative study could contribute to this investigation.

\section{Results and Discussion}

It is important to note that such a training model - the interactive learning model supported by ICT - is competency-to-gain-oriented, and is aimed at engaging students to various activities to create a learning intrigue and maintaining concentration, interest and motivation of a student to study. Furthermore, it goes in line with Sessoms (2008), performing group work (project work) under the supervision of the instructor motivates the students. The 
interactive learning model supported by ICT shows a potential to provide the purpose and tailored settings and self-study and self-reaching goals help students gain the feeling of self-confidence (Filatova \& Berezhnaya, $\mathrm{n} / \mathrm{d}$ ). Such a model is also aimed at developing self-education skills and skills, which are currently considered crucial and featured in the list of key life and career Skills of the $21^{\text {st }}$ Century (Bellanca \& Brandt, 2010).

A large number of scientists (Savchuk, 2014; Khlistun, 2014; Shuliak, 2017) note that without the use of modern means of information and communication technologies (hereinafter - ICT), it is impossible to imagine an educational process that meets the requirements of the modern information society (Roganovskaya, Poryadina, \& Nikitin, 2014), because modern education, the main characteristics of which remain openness, integration and individualization, should be based on modern information technologies. That is why, if in (Roganovskaya, Poryadina, \& Nikitin, 2014) ICT interpret as processes, methods for the search, collection, storage, processing, provision, dissemination of information and methods for implementing such processes and methods, then (Gradov, 2010) specifies the definition of ICT and sees it as an ICT in education, defining it with this concept: it is an integrated, multifaceted, resource-intensive process involving both students and teachers and the administration of higher education. In other words, it is the introduction of a complex of programs for managing process of education at higher educational establishments, the creation of a single information and communication educational space for higher education, the development of integrated occupations, project activities, as well as distance learning, network interaction, etc.

Along with the notions of "ICT", "ICT and education" the concept of "interactive model of learning" is actualized. Thus, the notion of "interaction" (Zhuk, \& Koshel, 2004) was first applied in social psychology. Definition of the concept of "interactive methods" developed from the definitions of the concepts "method" and "interactive" (interaction). Within the concept of "interaction" two elements can be distinguished: "inter" - between and "action" - enhanced activity. In this way, "interactions" can be interpreted as "enhanced" activity that occurs between people.

Consequently, "interactive methods" can be seen as a way of enhanced and targeted interpersonal interaction between students and a teacher (Information-analytical review, $n$./d.). Thus, the "interactivity" is considered to be a way of learning which is carried out with special forms aimed at joint activity among students. These forms help to contribute all students to be involved into active interaction with each other by sharing information, solving problems, modeling situations, evaluating colleagues' actions and their own behavior, immersing themselves into the real atmosphere of business collaboration aimed at solving problems. The concept of "interactivity" in the method involves the ability of participants of the learning process to interact actively in dialogue (conversation) with anyone (with a person) or anything (with a computer, for instance); interactivity involves the implementation of strategies and tactics for organizing joint activities.

Let us highlight the fact that during interactive learning a student becomes a full participant of the educational process whose content is the main source of the developed language and speech competences. The role of a teacher in this case is encouraging students to search independently. In contrast to traditional studying, with interactive learning, the interaction of a teacher and a student acquires a different character: the activity of the teacher is giving way to the activity of students, and the task of the teacher turns into creating the necessary conditions for their initiative (Gulyaeva, 2006). In work of Azimov and Shchukin (2009), the term "interactive learning" refers to learning based on the interaction of the student with the learning environment, which serves as a source of learned experience. Students turn out to be the full participants of the educational process whose content is the main source of the developed language competences. Researcher (Korotaeva, 2003) notes that "interactive learning is aimed at solving three tasks simultaneously: the educational and cognitive" (extremely specific), "communicative and developing" (related to general, emotional and intellectual background) and "social and oriented" (the results will occur outside the educational environment and time available for study). The researcher stresses that "interactive learning" is a process of joint cognition whereby knowledge is acquired as a result of joint activities through communication of students among themselves and with a teacher as well (dialogue, polylogue) (Korotaeva, 2003).

In this case, scientist Ostapenko (2007) notes that "interactive learning" is a learning that provides ongoing interaction between the subjects of the educational process. Interactive learning is based on the own experience of all participants engaged in learning. Therefore, knowledge is mastered due to their direct interaction with the industry. Researchers Filatova and Berezhnaya (n./d.), believe that "the essence of interactive learning" is that educational process is to be organized in such a way as to involve practically all students in the process of knowledge, as well as to provide them with an opportunity for reflection that they know. Foreign researchers place great emphasis on defining the concept of "interactive learning" and considering the place and role of interactive learning in the methodological process. 
Thus, it is worth noting that interactive learning, as a rule, should be characterized by appropriate informational and interactive environment. According to Demina (2015) observations, it should contain technological means of learning such as computer-based and mobile devices with a feedback which use the functionality of modern information technologies as efficiently as possible. That is why they serve as means of providing high-quality educational services to implement an active "dialogue" with all subjects of the educational process (Demina, 2015). Thus, one of the key elements in getting knowledge is the interactive means. The scholars Artyukhina, Artyukhin and Kleshnina (2014) consider "software-based, hardware-software and technical means and devices which operate on the basis of microprocessor and computing facilities providing learning in the dialogue between the user and the computer" to be these interactive means of learning.

One more question arose: what exactly are the means? The review of scholarly literature has demonstrated that when formulating the definition of "means" scholars tend to adhere to the following two positions: 1) some authors consider that these are such means of teaching as textbooks, teaching and learning materials etc., they help to provide the informational function of the educational process corresponding to the information tools; 2) the others, however, supplement the notion of "means" by the following components: activity of both the teacher and the student; teaching methods; ways and sequence of organization of the main elements of the educational process; "Training complex" on a particular subject (based on the leading role of the textbook), aimed at the most comprehensive realization of educational tasks; educational information and a project of educational activities, regardless of whether it is a printed medium, TV, computer or any other, including all of it in the concept of "textbook"; a system of educational methods.

According to Skakun (2009) views about the requirements for the means of instruction, it is especially important that the means of instruction, including interactive ones, should motivate and satisfy the interests of students, and also manage their activity. These components are important links in the mechanism of implementation and functioning of the entire information and interactive environment of higher education.

Thus, accumulating various interpretations of "means of instruction" it is necessary to emphasize that some researchers use information means, while others supplement educational activities with information means. According to Artyukhina, Artyukhin and Kleshnina (2014), Skakun (2009), Robert, Panyukova, Kuznetsov and Kravtsov (2008), among the interactive means in the teaching process of the Ukrainian language in higher education, we emphasize an interactive educational kit, which includes an interactive textbook, reference book, simulator, task book, laboratory workshop, means of visualization. Besides, interactive equipment includes interactive whiteboard, tablet, plasma display, mobile devices, projectors, testing systems, small IT tools. It should be noted that the effectiveness of interactive educational kit greatly depends on what equipment they will be presented on, and the interactive educational kit often cannot be opened without interactive equipment (Artyukhina, Artyukhin \& Kleshnina, 2014).

Speaking about the distribution of interactive means, some of the scientists Sessoms (2008) and Smith, Higgins, Wall and Miller (2005) pay great attention to the high professional competence of the teacher in the appliance of technological and methodological means, on which the quality of education depends directly. For example, researcher (Sessoms, 2008) talks about the technical and methodical means of interactivity. According to the authors Smith, Higgins, Wall and Miller (2005), a brief answer to this question is the combination of interactive education and interactive teaching, supported by technological tools. Combining the concepts of technical and methodical interactivity, they expand the positions of two innovative means, including interactive whiteboards and Web 2.0 tools.

Following the ideas of foreign authors Sessoms (2008) and Smith, Higgins, Wall and Miller (2005), we consider that among interactive means in teaching the Ukrainian language at higher educational establishments there should be interactive means. Such interactive means is connected with the necessity to create informational and interactive learning environment, which, in turn, will be the "means" that affect the provision of quality educational services in higher education, particularly on the philological faculties, etc., when it comes to the content of the academic discipline "Ukrainian language" in the aspect of interactive education.

This research has shown that the introduction of the interactive learning model supported by ICT in the educational process has the potential to intensify the educational activities of students of higher educational institutions of Ukraine. Teaching students with the use of this model increases the overall effectiveness of their learning activities, as they get the opportunity to study in their own pace, shifting the emphasis from creating an initial environment in the audience for autonomous learning of a student.

In addition, this study contributes to the study of the problem of integration of the interactive learning model 
supported by ICT in the educational activity of students of higher educational institutions in Ukraine, the use of methods for evaluating the effectiveness of such a training model, extends scientific ideas about the use of "the interactive learning model supported by ICT (multimedia textbook)" for the course (Professional purpose) Ukrainian Language for students through the example of those who specialize in Philology.

\section{Conclusion}

Summarizing the above-mentioned, the use of the interactive learning model supported by ICT (multimedia textbook) in the organization of educational activities of students of higher educational institutions positively affects the state of development of value-motivational, cognitive and activity-reflexive components of educational activity of students, and as an example - students of economic and managerial specialties. In general, students expressed positive opinion about the format and content of the course. Most students of the experimental group reported improvement in the results of communicative language skills, speed of thinking, and flexibility in problem solving, teamwork skills.

Moreover, we can state that among the information and communication technologies in education (complex, multifaceted, resource-intensive process involving students, teachers and administration at higher educational establishments) are represented, on the one hand, with the concept of "interaction" as a way of knowing, which is carried out in such forms of joint activity of students, in which all participants in the educational process can actively interact with each other, sharing information, jointly solving problems, modelling situations, assessing the actions of the count etc. and their own behaviour, plunging into the real atmosphere of business cooperation aimed at solving problems; on the other hand, with the concept of "interactivity", which includes the ability of the participants in the learning process to actively interact, while in a dialogue (conversation) with anyone (with a person) or with something (for example, with a computer). The interactivity involves the implementation of strategies and tactics for organizing joint activities.

In the modern methodology, the key concept is the concept of interactive education as a process of joint knowledge, in which knowledge is acquired as a result of joint activity through communication of students with each other and with the teacher (dialogue, polylogue), which is aimed at solving simultaneously three tasks: the educational-cognitive (very specific), communicative-developing (associated with the general, emotionally-intellectual background) and socially-oriented (the results will be manifested outside educational space and time). Implementation of interactive education, in particular, in the teaching the Ukrainian language in higher education, takes place through interactive means, among which we single out an interactive educational kit, which includes an interactive textbook, reference book, simulator, task book, laboratory workshop, means of visualization and interactive equipment which includes interactive whiteboard, tablet, plasma display, mobile devices, projectors, testing systems, small IT tools. Prospects for further research can be seen in a detailed examination of each individual type of interactive educational kit and interactive equipment.

\section{Acknowledgement}

This research was performed with the involvement of the English language teachers from Uman State Pedagogical University named after Pavlo Tychyna, Cherkasy National University named after Bohdan Khmelnytsky and National Pedagogical University named after Mikhailo Drahomanov. The Ukrainian language teachers from Uman State Pedagogical University named after Pavlo Tychyna participated in research as well.

\section{References}

Almazova, N. I. (2003). Cognitive aspects of the formation of intercultural competence in teaching a foreign language in a non-linguistic university. $\mathrm{PhD}$ thesis. St.-Peterburg.

Almarabeh, H., Amer, E. F. \& Sulieman, A. (2015). The Effectiveness of Multimedia Learning Tools in Education. International Journal of Advanced Research in Computer Science and Software Engineering, 5(12), 761-764.

Arnold-Garza, S. (2014). The flipped classroom teaching model and its use for information literacy instruction. Communications in Information Literacy, 8(1), 7-22. https://doi.org/10.15760/comminfolit.2014.8.1.161

Artyukhina, M. S., Artyukhin, O. I. \& Kleshnina, I. I. (2014). Hardware component of interactive technologies for educational purposes. Bulletin of Kazan Technological University, 17(8), 308-314.

Azimov, E. G. \& Shchukin, A. N. (2009). A new dictionary of methodological terms and concepts (theory and practice of teaching languages). Moscow: IKAR.

Babiker, M. (2015). For Effective Use of Multimedia in Education, Teachers Must Develop their Own Educational Multimedia Applications. The Turkish Online Journal of Educational Technology, 14(4), 62-68. 
Bellanca, J. \& Brandt, R. (2010). 21 st Century Skills: Rethinking How Students Learn (Leading Edge). Bloomington, IN: Solution Tree.

Bloom, B. S. (1976). Human Characteristics and School Learning. New York: McGraw-Hill.

Bolitho, R. \& West, R. (2017). The internationalization of Ukrainian universities: the English language dimension. Retrieved https://www.teachingenglish.org.uk/sites/teacheng/files/Pub-UKRAINE-REPORT-H5-EN.pdf

Brown, A. L. \& Campione, J. C. (1994). Guided discovery in a community of learners. In Classroom Lessons: Integrating Cognitive Theory and Classroom Practices, 229-270. Cambridge, MA: MIT Press.

Büyüköztürk, Ş. (2016). Data analysis handbook for social sciences. Ankara: Pegem A Yayıncılık.

Burns, C. \& Myhill, D. (2004). Interactive or inactive? A consideration of the nature of inter-action in whole class teaching. Cambridge Journal of Education, 34(1), 35-49. https://doi.org/10.1080/0305764042000183115

Demina, E. V. (2015). Informative interactive environment as a resource for the training of university teachers for research in the system of magistracy. Professional education in Russia and abroad, 1(17), 96-101.

Educause. (2012). 7 things you should know about flipped classrooms. Retrieved http://net.educause.edu/ir/library/pdf/ ELI7081.pdf

Filatova, O. G. \& Berezhnaya, M. A. (n./d.). The concept of interactive forms of learning. Retrieved http://www.bj.pu.ru/method/4-13.html

Fleming, N. \& Baume, D. (2006). Learning Styles Again: VARKing up the right tree! Educational Developments, 7(4), 4-7.

Giannakos, M. N., Krogstie, J., Sampson, D. (2018). Putting Flipped Classroom into Practice: A Comprehensive Review of Empirical Research. In: Sampson D., Ifenthaler D., Spector J., Isaías P. (eds) Digital Technologies: Sustainable Innovations for Improving Teaching and Learning. Springer, Cham. https://doi.org/10.1007/978-3-319-73417-0_2

Gradov, T. V. (2010). Information and communication technologies in the management of an educated institution. Information and communication technologies in teacher education, 5(9). Retrieved http://infed.ru/articles/42/

Gulyaeva, I. V. (2006). Formation of student subjectivity in interactive learning. Bulletin of Orenburg State University, 10, 31-35.

Gunawardhana, L. K. \& Palaniappan, S. (2016a). Possibility of using Multimedia Application for Learning. GSTF Journal on Computing, 5(1), 77-83. https://doi.org/10.7603/s40601-016-0012-0

Gunawardhana, L. K. \& Palaniappan, S. (2016b). Using Multimedia as an Education Tool. Retrieved https://www.academia.edu/24684294/Using_Multimedia_as_an_Education_Tool

Hall, J. K. \& Verplaetse, L. S. (2000). Second and foreign language learning through classroom interaction. Mahwah, NJ: Erlbaum. https://doi.org/10.4324/9781410605498

Information-analytical review. (n./d.). Interactive methods of teaching in educational institutions of higher professional education. Retrieved http://do.gendocs.ru/docs/index-235347.html

Khlistun, I. (2014). The problem of the formulation of the logistical structure of the Maybutnih teachers in the post-school school. In: Collection of scientific works of Uman State Pedagogical University named after Pavlo Tychyna: Psychological and pedagogical problems of the Silesian schools. Uman: FOP Zhovtyy O. O.

Kolesnikova, I. L. \& Dolgina, O. A. (2008). English-Russian terminological reference book on the methodology of teaching foreign languages: information manual. Moscow: Drofa.

Korotaeva, E. V. (2003). Teaching technologies in the cognitive activity of schoolchildren. Moscow: Sentyabr.

Norlis, O., Ramli, R. Z. \& Taib, J. M. (2018). Multimedia Education Tools for Effective Teaching and Learning. Journal of Telecommunication, Electronic and Computer Engineering, 9(2-8), 143-146.

Ostapenko, A. A. (2007). Modeling pedagogical reality: theory and technology. Moscow: Narodnoe Obrazovanie.

Robert, I. V., Panyukova, S. V., Kuznetsov, A. A. \& Kravtsova, A. Yu. (2008). Teaching-methodical manual. Moscow: Drofa.

Roganovskaya, E. N., Poryadina, L. N. \& Nikitin, P. V. (2014). Use of innovative technologies in the educational process. Krasnoyarsk: Information Center, Central Research Institute "Monograph". 
Savchuk, N. M. (2014). Motivationally connected words in colloquial vocabulary (based on the material of Ukrainian literary literature of the end of XX - beginning of the XXI century). Proceedings of the International Internet Conference: Current problems in Applied Linguistics. Uman, Ukraine, April, 24-25.

Sessoms, D. (2008). Interactive instruction: Creating interactive learning environments through tomorrow's teachers. International Journal of Technology in Teaching and Learning, 4(2), 86-96.

Shuliak, S. (2017). Magical language of Ukrainian folk orders: monograph. Uman: "Sochinsky MM".

Skakun, V. A. (2009). Methods of Teaching Special and General Technical Objects. Moscow: Academiya.

Smith, H. J., Higgins, S., Wall, K. \& Miller, J. (2005). Interactive whiteboards: Boon or bandwagon? A critical review of the literature. Journal of Computer Assisted Learning, 21, 91-101. https://doi.org/10.1111/j.1365-2729.2005.00117.x

Sun, J. C. Y. \& Wu, Y. T. (2016). Analysis of learning achievement and teacher-student interactions in flipped and conventional classrooms. The International Review of Research in Open and Distributed Learning, 17(1). https://doi.org/10.19173/irrodl.v17i1.2116

Thamarana, S. (2016). Critical study of the use of interactive multimedia technologies in English classes. International journal of English language, literature and translation studies, 3(3), 50-54.

Udim, D. K. \& Etim, E. A. (2016). Use of multimedia in teaching and learning of political science in university of UYO, Akwa Ibon State, Nigeria. Research in Pedagogy, 6(2),154-170. https://doi.org/10.17810/2015.42

Zhuk, A. I. \& Koshel, N. N. (2004). Active methods of teaching in the system of professional development of teachers. Moscow: Aversave. 